\title{
Ocorrência de Colletotrichum gloeosporioides (Penz.) Sacc. em Carthamus tinctorius L. no estado do Paraná
}

\author{
Solange Monteiro de Toledo Pizza Gomes Carneiro, Michele Regina Lopes da Silva, Euclides Bueno Romano, \\ Leandro Camargo Borsato, Tatiana Marianowski, José Carlos Gomes
}

Instituto Agronômico do Paraná - IAPAR, Rodovia Celso Garcia Cid, Km 375, Caixa Postal 481, CEP 86001-970, Londrina, PR. Autor para correspondência: Solange Monteiro de Toledo Piza Gomes Carneiro (solange_carneiro@iapar.br) Data de chegada: 09/02/2011. Aceito para publicação em: 13/02/2012.

\section{RESUMO}

Carneiro, S.M.T.P.G.; Silva, M.R.L.; Romano, E.B.; Borsato, L.C.;Marianowski, T.; Gomes, J.C.. Ocorrência de Colletotrichum gloeosporioides (Penz.) Sacc. em Carthamus tinctorius L. no estado do Paraná. Summa Phytopathologica, v.38, n.2, p.163-165, 2012.

O cártamo (Carthamus tinctorius) é uma espécie cultivada de importância medicinal e industrial e atualmente é considerado uma planta de grande potencial na produção de biodiesel. O objetivo deste trabalho foi verificar qual o agente causal das manchas observadas em plantas de cártamo presentes no campo experimental do IAPAR em Londrina-PR. Foram realizados isolamentos a partir de lesões foliares de plantas sintomáticas e realizado teste de patogenicidade dos isolados em plantas sadias de cártamo. As plantas inoculadas apresentaram sintomas de antracnose nas folhas, nas hastes e no capítulo, assim como morte das plântulas. A observação e análise de estruturas reprodutivas do fungo em meio de cultura e no tecido do hospedeiro, assim como a PCR táxon-específica permitiu a identificação dos isolados do fungo comb pertencentes à espécie Colletotrichum gloeosporioides. Este foi o primeiro relato de antracnose por $C$. gloeosporioides em cártamo no estado do Paraná.

Palavras-chave adicionais: antracnose; cártamo; patogenicidade; PCR.

\section{ABSTRACT}

Carneiro, S.M.T.P.G.; Silva, M.R.L.; Romano, E.B.; Borsato, L.C.; Marianowski, T.; Gomes, J.C. Occurence of Colletotrichum gloeosporioides (Penz.) Sacc. in Carthamus tinctorius L., in the Paraná state. Summa Phytopathologica, v.38, n.2, p.163-165, 2012.

The safflower (Carthamus tinctorius) is a crop of medicinal and industrial importance and is now considered a plant of great potential to biodiesel production. The objective of this study was to verify the causal agent of the spots observed in safflower plants in the IAPAR experimental field in Londrina-PR. Isolations were made from leaf lesions of symptomatic plants and pathogenicity test of the isolates in healthy plants of safflower. The inoculated plants showed symptoms of anthracnose on leaves, stems and the flower bud, and death of seedlings. The observation and analysis of reproductive structures of the fungus in media culture and in host tissue, as well as taxon-specific PCR allowed the identification of the fungus as belonging to Colletotrichum gloeosporioides specie. This was the first report of anthracnose caused by C. gloeosporioides in safflower in Parana state.

Additional keywords: anthracnose; safflower; pathogenicity; PCR.

O cártamo (Carthamus tinctorius L.) é uma espécie da família Asteraceae cultivada no mundo todo devido a sua importância medicinal e industrial. As folhas, pétalas e sementes de cártamo possuem propriedades medicinais e terapêuticas. Suas sementes, que possuem cerca de $30 \%$ de óleo, o tornam uma planta de grande potencial na produção de biodiesel (2). O gênero Colletotrichum é um dos mais importantes entre os fungos fitopatogênicos, especialmente nas regiões tropicais e subtropicais do mundo. Esse gênero apresenta espécies que causam doenças economicamente importantes em cereais, leguminosas, hortaliças, culturas perenes, frutíferas, incluindo muitas espécies ornamentais (7). A antracnose do cártamo, causada por Colletotrichum gloeosporioides (Penz.) Sacc., já foi descrita apenas no estado de São Paulo por Ribeiro \& Cervellini (6). O objetivo deste trabalho foi verificar qual o agente causal das manchas observadas em plantas de cártamo coletadas no estado do Paraná.
Em março de 2007, no campo experimental do IAPAR em Londrina, $\mathrm{PR}$, constatou-se a ocorrência de manchas de coloração marrom escuro nas folhas e hastes em plantas de cártamo. Em laboratório, pequenas secções das lesões foliares foram desinfestadas em solução de hipoclorito de sódio $1 \%$ por $1 \mathrm{~min}$, depositadas em placas de Petri contendo meio de cultura PGA (Ágar Peptona Glicose) pH 6,0 e incubadas em câmara tipo B.O.D. durante sete dias a $26^{\circ} \mathrm{C}$ no escuro. $\mathrm{O}$ isolado fúngico foi submetido à cultura monospórica e em seguida aos testes de caracterização e identificação do fungo.

Plantas sadias de cártamo em diferentes fases de desenvolvimento foram usadas para o teste de patogenicidade. Foram utilizadas 16 plantas semeadas em vasos plásticos de $2 \mathrm{~L}$ contendo 3 partes de terra e 1 parte de areia mantidas em casa de vegetação. As plantas foram inoculadas por pulverização com suspensão de esporos do fungo na concentração $10^{6}$ conídios $\mathrm{mL}^{-1}$, mantidas em câmara úmida por 48 

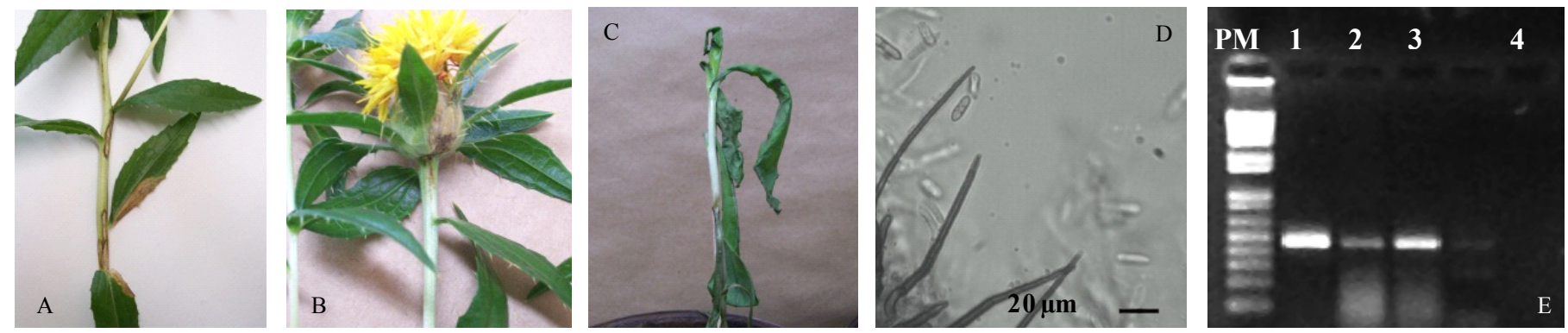

Figura 1. Sintomas de antracnose na haste e folhas $(1 \mathrm{~A})$, nos capítulos $(1 \mathrm{~B})$, em plântulas de cártamo (C). Aspecto de conídios e setas de Colletotrichum gloeosporioides $(1 \mathrm{D}$, barra $=20 \mu \mathrm{m})$. Produto da amplificação de DNA genômico $(450 \mathrm{pb})$ com os primers Cg Interno e ITS 4 . (1E) Peso molecular $1 \mathrm{~Kb}$ plus (PM), Colletotrichum gloeosporioides isolado de cafeeiro (1), isolado de cártamo (2) e isolado de cártamo reisolado no teste de Koch (3), controle negativo (4).

Tabela 1. Dimensão de estruturas de Colletotrichum gloeosporioides desenvolvidas em meio de cultura Ágar Peptona Glicose (PGA) e sobre tecido de cártamo.

\begin{tabular}{lcccc}
\hline \multirow{2}{*}{ Substrato } & \multicolumn{3}{c}{ Estrutura } \\
\cline { 2 - 3 } & Comprimento $(\mu \mathrm{m})$ & Largura $(\mu \mathrm{m})$ & & Comprimento $(\mu \mathrm{m})$ \\
Meio PGA & $14,1^{* *}$ & $5,2 \mathrm{~ns}$ & $94,5^{* *}$ \\
& $(10-20)^{1}$ & $(5,0-7,5)$ & $(55,0-145,0)$ \\
Cártamo & 19,8 & 5,0 & 82,8 \\
\hline
\end{tabular}

** diferença significativa na média (coluna) pelo teste t-Student a $1 \%$ de significância. ${ }^{1}$ Amplitude da média. Ns = não significativo.

horas a $21{ }^{\circ} \mathrm{C}$ e então transferidas para casa de vegetação. Plantas testemunhas foram inoculadas com água e mantidas nas mesmas condições.

$\mathrm{O}$ reisolamento do fungo a partir dos tecidos inoculados foi realizado em meio de cultura PGA 11 dias após a inoculação do isolado nas plantas. A análise morfológica do isolado foi realizada a partir de estruturas fúngicas desenvolvidas em meio de cultura PGA e também nos ramos e folhas de plantas de cártamo submetidos à câmara úmida por 48 horas.

A observação e mensuração das estruturas fúngicas foi realizada em microscópio óptico. Foram mensurados 100 conídios e 50 setas para cada substrato e os resultados submetidos ao teste t-Student.

A confirmação da espécie de Colletotrichum foi realizada por PCR táxon-específica, tanto para o isolado do fungo reisolado da planta no teste de Koch quanto para outro isolado obtido posteriormente no campo experimental de Londrina. Para a extração de DNA os isolados foram cultivados em meio de cultura YPD (Yeast Peptone Dextrose) a $25^{\circ} \mathrm{C}$ sob agitação durante sete dias. $\mathrm{O}$ micélio foi coletado por filtração a vácuo e macerado com auxílio de nitrogênio líquido. A extração do DNA genômico foi realizada de acordo com a metodologia descrita por Raeder \& Broda (5). Para amplificação foram utilizados os primers ITS4 (8) e Cg Interno (1) de acordo com a metodologia descrita por Freeman et al. (3), em termociclador PTJ-100-60 (MJ Resarch, Inc., Watertown, MA, EUA). O produto da amplificação foi submetido à eletroforese $(5 \mathrm{~V} / \mathrm{cm})$ em gel de agarose $(1 \%)$ em tampão Tris ácido acético EDTA 1X (TAE), corado com brometo de etídeo $(0,2 \mu \mathrm{g} / \mathrm{mL})$ e fotografado pelo sistema Kodak EDAS 120 (Eastmam Kodak Company, Rochester, NY, EUA).

As plantas inoculadas apresentaram sintomas de antracnose nas folhas, nas hastes (Figura 1A) e no capítulo (Figura 1B) assim como morte de plântulas (Figura 1C). As manchas foliares apareceram sete dias após a inoculação do fungo, sendo que lesões nas nervuras provocaram o rompimento do tecido e a necrose do limbo foliar em torno da lesão. Nas hastes foram observadas lesões deprimidas, com bordo castanho-escuro e centro pardo. Os capítulos quando infectados ainda jovens, desenvolveram lesões necróticas que se expandiram afetando toda a estrutura reprodutiva. As plantas testemunhas não apresentaram sintomas de infecção pelo fungo. Assim foi possível confirmar a patogenicidade do isolado do fungo pelo cumprimento dos Postulados de Koch.

A morfologia e dimensão das estruturas fúngicas observadas estão de acordo com os relatos presentes na literatura (4) para a espécie Colletotrichum gloeosporioides. Os conídios apresentaram-se cilíndricos, hialinos, unicelulares, formados em acérvulos com a presença de setas (Figura 1D). Foram observadas diferenças significativas tanto no comprimento dos conídios do fungo como no comprimento das setas nos acérvulos, conforme o substrato fornecido para seu desenvolvimento (Tabela 1).

A análise do conídio desenvolvido no próprio tecido do hospedeiro é importante para uma caracterização mais precisa do fungo. A mensuração das estruturas fúngicas mostrou que existe diferença entre o comprimento dos conídios e das setas nos acérvulos do fungo cultivado em meio de cultivo e no tecido do hospedeiro. Contudo, as dimensões dos conídios desenvolvidas pelo fungo em ambos os substratos encontram-se dentro da faixa descrita na literatura (4) para a espécie C. gloeosporioides.

A amplificação do DNA do isolado fúngico com os primers $\mathrm{Cg}$ Interno e ITS4 resultou em produto de aproximadamente $450 \mathrm{pb}$ 
(Figura 1E), possibilitando a confirmação da identificação desse isolado como pertencente à espécie C. gloeosporioides.

Este foi o primeiro relato de antracnose causada por $C$. gloeosporioides em plantas de cártamo no estado do Paraná, onde as condições climáticas podem favorecer o desenvolvimento da doença nesta cultura.

\section{REFERÊNCIAS BIBLIOGRÁFICAS}

1. Brown, A.E.; Sreenivasaprasad, S.; Timmer, L.W. Molecular characterization of slow-growing orange and Key Lime anthracnose of Colletotrichum from citrus as C. acutatum. Phytopathology, St. Paul, v.86, n.5, p.523-527, 1996.

2. Dwivedi, S.L.; Upadhyaya, H.D.; Hegde, D.M. Development of core collection using geographic information and morphological descriptors in safflower (Carthamus tinctorius L.) germplasm. Genetic Resources and Crop Evolution, Dordrecht, v.52, n.7, p. $821-830,2005$.

3. Freeman, D.S.; Minz, D.; Maymon, M.; Zveibil, A. Genetic diversity within Colletotrichum acutatum sensu Simmonds. Phytopathology, St. Paul, v.91, p.586-592, 2001.

4. Mordue, J.E.M. Glomerella cingulata. Kew. Commonwealth Mycological Institute,_1971. 2 p. (Descriptions of Pathogenic Fungi and Bacteria, $\mathrm{n}^{\circ} 315$ ).

5. Raeder, U; Broda, P. Rapid preparation of DNA from filamentous fungi. Letters in Applied Microlbiology,Oxford, v.1, p.17-20, 1985.

6. Ribeiro, I.J.A.; Cervellini, G.S. Antracnose do cártamo (Carthamus tinctorius L.) causada por Colletotrichum gloeosporioides no estado de São Paulo. Bragantia, Campinas, v.30, p.39-42, 1971.

7. Sutton, B.C. The Coelomycetes. Kew: Commonwealth Mycological Institute, 1980. 696p.

8. White, T.J.; Bruns, T.; Taylor, J. Amplification and direct sequencing of fungal ribosomal RNA genes for phylogenetics. In: Innis, M.A.; Gelfand, D.H.J.J; Shinsky, T. J. PCR Protocols: a guide to methods and applications. New York: White Academic Press, 1990. p.315-322. 